\title{
O catolicismo latino-americano radicalizado
}

Michel Löwy

Traduçáo: Mário Laranjeira*

Uma das principais críticas da Congregação para a Doutrina da Fé à teologia da libertação é o seu imanentismo historicista: a sua identificação do devir do Reino de Deus com o movimento de libertação humana. Em sua resposta ao Vaticano, os irmãos Boff (Leonardo e Clovis) observam que a teologia da libertação concebe a história de Deus na história humana, sem com isso confundi-las nem separá-las. Para certos representantes desta corrente, a libertação histórica é uma antecipação da salvação total (Scannone ${ }^{1}$ ), para outros há até uma relação causal entre as duas (Luis Segundo ${ }^{2}$ ). Mas todos estão de acordo para criticar uma teologia dualista que desistoriciza a Deus; segundo Hugo Assmann ${ }^{3}$, tal concepção é fundamentalmente antibíblica e procede antes da filosofia grega...

\section{O Antimodernismo Cat6lico... Modernizado}

E enquanto narrativa da manifestação de Deus na história que o Antigo Testamento $\epsilon$ essencial para a teologia da libertaçăo. Mas, para compreender a sua leitura do Antigo Testamento, é preciso primeiro circunscrever a sua concepçāo da história atual, que a uma só vez comporta aspectos antimodernistas crítica da modernidade capitalista, nostalgia da comunidade orgânica - e aspectos radicalmente modernistas: valorização da liberdade, da igualdade, da democracia, do socialismo. Longe de se contradizerem, esses aspectos acabam por se tornar complementares no seio de um procedimento coerente e original, como vamos ver com alguns exemplos:

\section{A Crfitica da Modernidade Econômica}

Essa crítica do capitalismo e do liberalismo é uma velha tradição da Igreja católica. Max Weber năo estudou exatamente as relações entre a ética católica e o espírito do capitalismo, mas no seu estudo sobre o protestantismo pode-se ler quase que por contraste algumas indicaçōes sobre as causas da antipatia fundamental que existe entre a racionalidade ética do catolicismo e a racionalidade econômica impessoal do capitalismo. O motivo essencial 6 o seguinte:

"Toda relação puramente pessoal, de homem a homem, qualquer que seja, incluindo a redução da escravatura, pode ser eticamente regulamentada, podem-se estabelecer postulados éticos, pois a estrutura dessa relaçăo depende da vontade pessoal dos participantes deixa pois o campo livre ao

* Reproduzido, com permissão, de Lettre: temps présent, no 344-345, juillet-août, 1987.

1 Theology, popular culture and discernment.

2 Capitalism versus socialism: crux theologica. In: GIBELLINI, R. Frontiers of theology in Latin America. Mary Knoll/New York, Orbis Books, 1973. p. 230, 257.

3 Theology for a Nomad Church. Mary Knoll/New York, Orbis Books, 1973. p. 74-5. 
desenvolvimento da virtude da caridade. Mas assim não são as relaçōes comerciais racionais, e são-no tanto menos quanto mais racionalmente diferenciados. (...) $O$ universo funcionalizado do capitalismo não oferece nenhum lugar para essa orientação caridosa. Não somente as exigências da caridade religiosa esbarram, como por toda parte, nos casos particulares, no humor recalcitrante e na insuficiência das pessoas concretas, mas ainda perdem qualquer espécie de sentido. À ética religiosa opóe-se um mundo de relações interpessoais que, em princípio, não pode dobrar-se às normas originais (...). Por conseguinte, com uma ambigüidade característica, o clero sempre sustentou o patriarcalismo, no interesse do tradicionalismo, contra as relaçōes impessoais de dependência, embora, por outro lado, a profecia rompa os laços patriarcais" 4 .

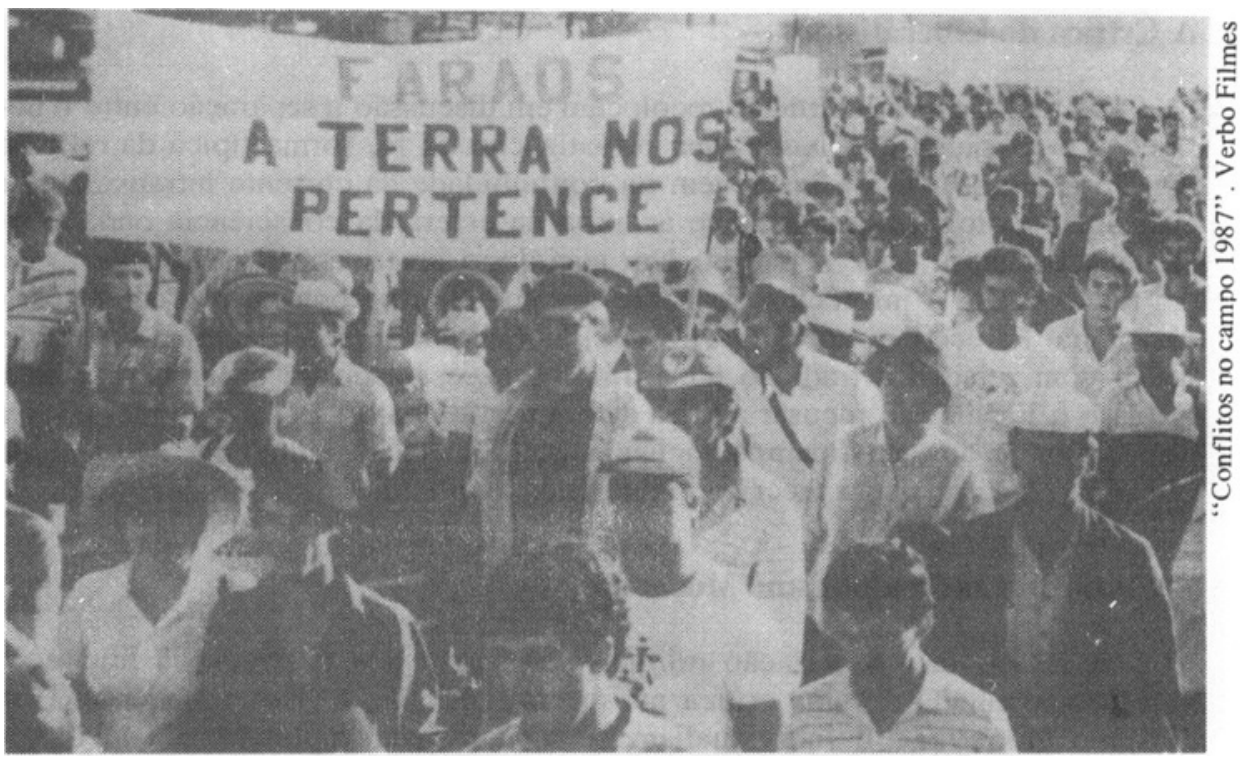

Certos sociólogos brasileiros acham que essa análise weberiana e diretamente aplicável ao Brasil e nos permite compreender as críticas da Igreja em relaçâo ao desenvolvimento capitalista nas áreas rurais. Nâo é essa a minha opinião, na medida em que essa Igreja não defende mais o patriarcalismo, mas a indicação de Weber sobre a profunda oposição existente entre a racionalidade ética católica e a racionalidade econômica do capital me parece um bom ponto de partida para compreender o que se passa na América Latina. zando-a:

Herdeira dessa tradição católica, a teologia da libertação inova moderni-

a) ao radicalizá-la e ao generalizá-la para todo o capitalismo;

b) ao juntar à leitura moral do capitalismo uma análise econômica;

c) ao passar do conceito de caridade ao de justiça social;

d) ao não valorizar um modelo passado, mas promover uma caminhada para o futuro (utopia social).

Seria pois um erro grosseiro querer explicar unicamente por influência do marxismo a hostilidade da teologia da libertação (ou dos bispos que the são chegados) à ordem econômica existente. A sua rejeição ao esptrito do capitalismo $\epsilon$ antes de tudo ética e remonta às fontes antigas e pré-modernas da cultura católica - o que a torna muito mais intransigente do que a de muitas correntes marxistas. Um exemplo basta para ilustrar esta afirmação aparentemente pa-

4 WEBER, M. Economie et société. Paris, Plon, 1971. p. 591-2. Versachlicht significa mais reificado do que funcionalizado. 
radoxal: enquanto o Partido Comunista Brasileiro explicava nas resoluçōes de seu IV Congresso (1967) que "a socialização dos meios de produção não corresponde ao nível atual da contradição entre forças produtivas e relaçōes de produção", em outros termos, que o capitalismo industrial pode ainda desempenhar um papel progressista no Brasil - os bispos da regiâo Centro-Oeste do Brasil publicam, em 1973, um documento, O Grito das Igrejas, cuja conclusão afirma:

"É preciso vencer o capitalismo. É ele o mal maior, o pecado acumulado, a raiz estragada, a árvore que produz esses frutos que nós conhecemos: a pobreza, a fome, a doença, a morte da grande maioria. Por isso é preciso que a propriedade dos meios de produção (das fábricas, da terra, do comércio, dos bancos, fontes de crédito) seja ultrapassada"5.

\section{A Crítica do Liberalismo}

Os teólogos da libertação recolocam em discussão a separação entre o político e o religioso que induz uma privatização da $f \in$, forma típica da religião burguesa. Nisso eles se inscrevem na continuidade da corrente intransigente e criticam a teologia liberal que se acantoa na esfera da consciência onde a sociedade burguesa quer mantê-la. Um sociólogo americano, Ivan Vallier ${ }^{6}$, vê, em razão disso, a influência do padre revolucionário como retrógrada e tradicionalista. Parece-me, ao contrário, que, também nisso, a teologia da libertação inova com relação à tradição ao afirmar a necessidade da separação entre a Igreja e o Estado, ao recusar a idéia de um partido cat6lico, ao defender a idéia da autonomia dos movimentos sociais e políticos. Para Gutierrez, não se trata de voltar ao catolicismo precrítico (referência explícita à filosofia das Luzes).

\section{A Crítica do Individualismo Moderno}

A recusa da privatização religiosa por parte dos teólogos da libertação vem acompanhada de uma crítica mais geral do individualismo moderno. Para Gustavo Gutierrez "o individualismo é a nota mais importante da ideologia moderna e da sociedade burguesa. Para a mentalidade moderna, o homem é um começo absoluto, um centro autônomo de decisōes. A iniciativa e o interesse individuais são o ponto de partida e o motor da atividade econômica". Ele menciona nesse contexto os trabalhos de Lucien Goldmann, que havia posto em evidência a oposição entre a religiāo como sistema de valores transindividuais e a problemática estritamente individualista das Luzes e da economia de mercado. A conclusão $\epsilon$, pois, que "o espiritual, para usar uma expressão corrente, não se opõe ao social. A verdadeira oposição está entre o individualismo burguês e

5 Documentos do Partido Comunista Brasileiro. Lisboa, Ed. Avante, 1976. p. 71. Los Obispos Latinoamericanos entre Medelin y Puebla. San Salvador, Universidad CentroAmericana, 1978. p. 71. Para um estudo circunstanciado e esclarecedor das relaçōes entre a teologia da libertação e o marxismo, veja-se o ensaio de Guy Petitdemange: "Théologie(s) de la libération et marxisme(s)", na brochura Pourquoi la théologie de la libération?. Suplemento n= 307 dos Cahiers de lactualité religieuse et sociale, março de 1985. Para o papel particular das ciências sociais marxistas (principalmente a teoria da dependência) na América Latina em relação às correntes cristãs engajadas, veja-se o estudo de Gonzalo Arroyo: "Genèse et développement de la théologie de la libération". Recherches de Science Religieuse, 74 (2), abril-junho de 1986. Uma excelente apresentação histórica da convergência política entre cristãos e marxistas 6 o ensaio de Enrique Dussel: "Encuentros de cristianos y marxistas en América Latina" em: Cristianismo y Sociedad. Santo Domingo, n= 74, 1982.

6 VALLIER, I. Radical priests and revolution. In: CHALMERS, D. Change in Latin America. Nex interpretations of its politics and society. New York, Academy of Political Science, 1972. p. 17, 21, 23. 
o espiritual segundo a Bíblia"7. A alternativa autêntica para o recolhimento egoísta sobre o indivíduo é por certo a comunidade, cuja forma concreta atual são as comunidades eclesiais de base. Tratar-se-ia da comunidade orgânica, tradicional, pré-moderna? Sim e não. Sim, na medida em que, em face de uma sociedade moderna que, segundo Leonardo Boff, "gera uma atomização da existência e um anonimato generalizado das pessoas", trata-se de criar "comunidades em que as pessoas se conheçam e se reconheçam", caracterizadas pelas "relações diretas, pela reciprocidade, pela fraternidade profunda, a ajuda mútua, a comunhāo das idéias evangélicas entre os membros". Todavia, a comunidade integral $€$ uma utopia, impossível de realizar-se atualmente em estado puro: no que tange à Igreja, não se trata de negar a instituição, mas simplesmente fazer renascer a sua dimensão comunitária que corresponde a uma "legítima e antiga tradição", que permaneceu durante muito tempo "em estado latente, como brasa sob cinzas" costumes populares (principalmente de origem rural) que resistiram ao processo de urbanização e modernização; mas elas não são a simples reprodução de relaçōes sociais pré-modernas. Como observa muito pertinentemente Harvey $\operatorname{Cox}^{9}$, elas constituem um aspecto de "escolha individual" que é tipicamente moderna, gerando formas de "solidariedade" novas que nada têm a ver com as estruturas arcaicas tribais ou aldeãs. Por esse aspecto moderno, pode-se considerá-las como agrupamentos voluntários utópicos, no sentido que Jean Seguy ${ }^{10}$ dá a esse conceito, isto é, agrupamentos de que os membros participam com adesão total e que visam (implícita ou explicitamente) a transformar - de maneira radical os sistemas sociais globais existentes.

\section{Do Pobre ao "Pobretariado"}

Chegamos assim àquilo que constitui, na visão da história atual e presente da América Latina, o núcleo mais importante e mais inovador da teologia da libertação: a autolibertação dos pobres como movimento histórico rumo ao Reino de Deus. $O$ interesse pelo pobre enquanto vítima inocente e digna de misericórdia, característica da tradição da Igreja, articula-se aqui com a idéia moderna do pobre como classe social explorada e oprimida que busca libertar-se. Isso não quer dizer que a teologia da libertação reduza o pobre ao proletário: o conceito mantém aqui um sentido muito mais amplo, a um tempo por suas conota-

(...) o núcleo mais importante e mais inovador da teologia

da libertação: a

autolibertaçäo dos pobres como movimento histórico rumo ao Reino de

Deus. çōes morais e por sua extensão social. Trata-se, segundo Gutierrez ${ }^{11}$, do conjunto das classes exploradas, das raças desprezadas e das culturas marginalizadas. Corresponde também à realidade social da América Latina, onde se encontra, tanto nas cidades como nos campos, uma massa enorme de pobres - desempregados, semidesempregados, marginais, bóias-frias, vendedores ambulantes, etc. - excluídos do sistema de produção formal. Os sindicalistas cristãos/marxistas de El Salvador inventaram um termo que associa todos os componentes da população pobre e dominada: o "pobretariado".

${ }^{7}$ GUTIERREZ, G. La force historique des pauvres. p. 172-73, 218.

${ }^{8}$ BOFF, L. Eglise en Genèse. Les communautés de base. Paris, Desclée, 1978. p. 7-8, 14-15 e 21.

${ }^{9}$ Religion in the secular city, toward a post-modern Theology. New York, Simon \& Schuster, 1984. p. 127. Cf., também, p. 131: "as comunidades de base incorporam elementos ao mesmo tempo da crítica tradicional e da crítica radical do mundo moderno".

${ }^{10}$ Lettre à Jacqueline $n^{o}$ 3. Seminário "Protestation socio-religieuse et contre-culture". E.P.H.E., 1973-1974. p. 11.

11 La force... op. cit., p. 99-100. 


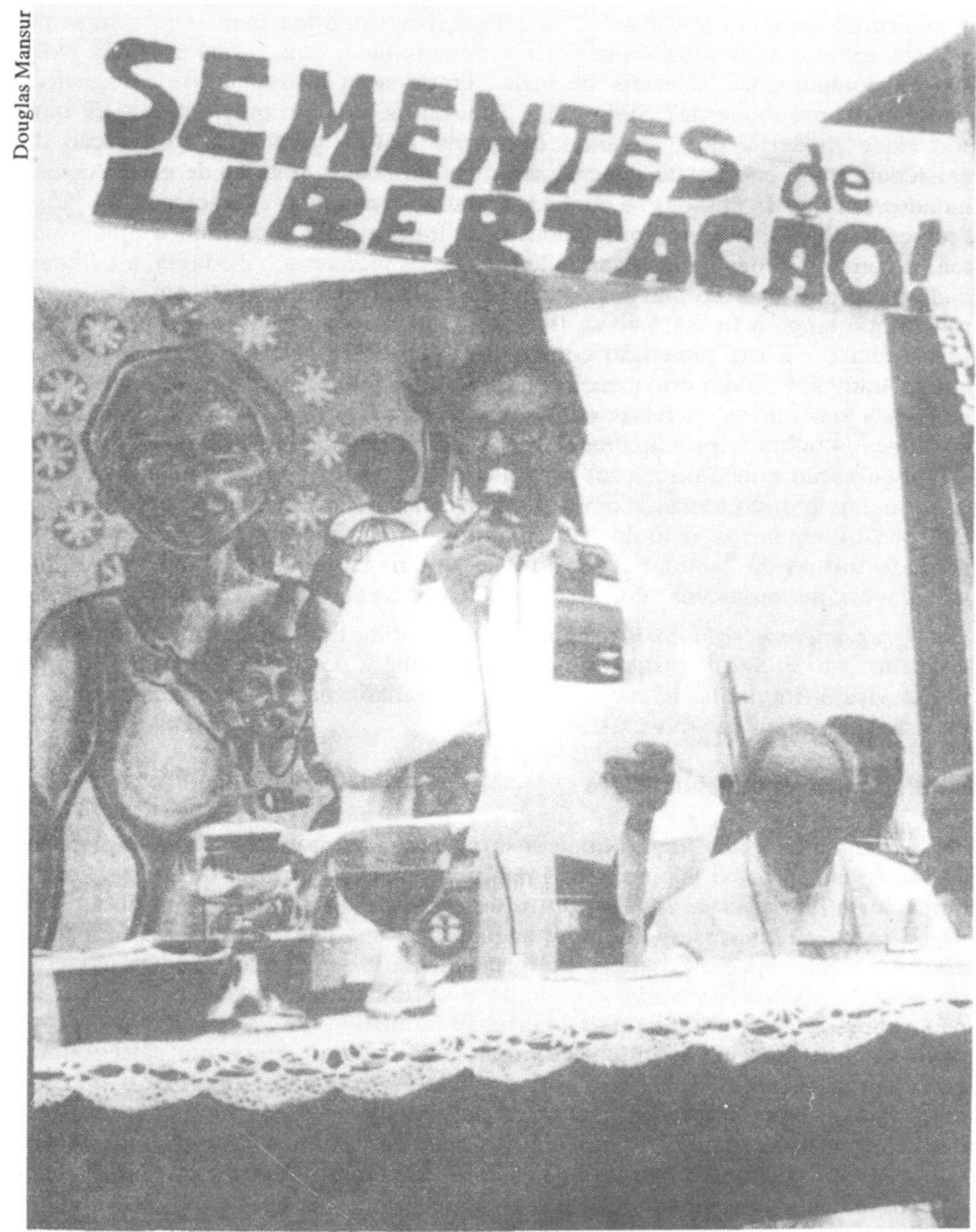

Se o interesse pelo pobre $\in$ de fato uma tradição cristã, antiga, o acontecimento novo é a afirmação de que os pobres serão "os agentes de sua própria libertação e o sujeito da sua própria historia" - e não simplesmente o objeto de uma atenção paternalista, caridosa e assistencial ${ }^{12}$.

Em maior profundidade, tal procedimento implica também uma ruptura com toda concepção passiva ou de simples espera com relação à intervenção divina: em sua declaração de 1973, os bispos e superiores religiosos do Nordeste brasileiro criticam a imagem de Deus apresentada freqüentemente "como um 'Deus mágico', substituindo o homem e assumindo a sua responsabilidade histórica" 13. A idéia-força da autolibertação dos pobres - que apresenta uma afinidade evidente com alguns temas clássicos do marxismo ("a emancipação

12 Id., Théologie de la libération. Perspectives. Bruxelas, Lumen Vitae, 1974. p. 301, 305; e BOFF, L. Igreja, carisma e poder. Petrópolis, Vozes, 1982. p. 26-7.

${ }^{13}$ Los bispos latinoamericanos de Medelin a Puebla. 1973. p. 47. 
dos trabalhadores será a obra dos proprios trabalhadores") - abre evidentemente um enorme campo de ação para os cristãos engajados e constitui assim o elemento mais explosivo da teologia da libertação. Segundo o ponto de vista do Vaticano, trata-se naturalmente de um procedimento manchado de imanentismo historicista, contra o qual a Instrução da Congregação para a Doutrina da Fé apresenta a sua própria hermenêutica da Bíblia:

"Os salmos nos remetem a uma experiência religiosa essencial: só de Deus se pode esperar a salvação e o remédio. Deus, não o homem, tem poder para mudar situaçōes de penúria. Assim os 'pobres do Senhor' vivem numa dependência total e confiante na amorosa providência de Deus"14.

Outra crítica reveladora contra esse aspecto da teologia da libertação é adiantada pelo leigo inglês Dale Vree:

"Gutierrez quer afirmar que o Reino por vir é antes de tudo um dom, mas deve-se concluir do que ele diz que o Reino por vir é antes de tudo um produto da açảo humana"15.

\section{A Bíblia Judaica Redescoberta}

E a partir dessa concepção da história atual e da realidade social na América Latina que a teologia da libertaçāo avança determinada leitura do Antigo Testamento. Antes de mais nada, é visível que o Antigo Testamento nela ocupa um lugar muito mais importante do que a que the $\epsilon$ habitualmente reservada pela teologia católica. Segundo a Congregação para a Doutrina da Fé, ésse procedimento "conduz à negação da total novidade do Novo Testamento" 16 . Para certos partidários da teologia latino-americana, como o leigo Adolfo AbascalJaen, $\boldsymbol{\epsilon}$ ao contrário a corrente conservadora que peca por marcionismo:

"A sua leitura da Biblia diminui a tal ponto a importância do Antigo Testamento que não deixa de lembrar a do herege Marcião no século II"17

É certamente por seu caráter histórico e social, enquanto testemunho da presença de Deus na história, que o Antigo Testamento fascina os te6logos da libertação. O seu interesse se volta principalmente para três momentos da mensagem bíblica:

a) A palavra dos profetas enquanto crítica dos poderosos e denúncia da injustiça social;

b) A promessa messiânica do Reino de Deus;

c) O Exodo.

Limitar-me-ei aqui a examinar este terceiro momento.

O Êxodo é o livro bíblico por excelência em que Deus "se revela nos acontecimentos históricos", em que Deus "salva na história". Ora, esta história É a de uma libertação social e política em que "o fato religioso não aparece como algo à parte" mas se situa no "contexto total" e "dá à narrativa toda o

14 CONGREGAÇÃO para a DOUTRINA da FÉ. Instrução sobre alguns aspectos da teologia da libertação. In: - . Teologias da libertação. Documentos e Debates. Paris, Le Cerf/Le Centurion, 1985. p. 161.

15 Christian Marxists: a critique. In: QUADE, Q.L. The pope and revolution.John Paul, confronts liberation theology. Washington, Ethics and Public Policy Center, 1981. p. 43.

16 Teologias da libertação... op. cit., p. 175.

17 L'offensive contre la thélogie latino-américaine de la libération. Liaisons Internationales. Bruxelas, (40): 6, nov. 1984. 
seu sentido profundo"18. A Congregação vaticana não deixou de evidenciar a sua discordância sobre essa questão:

"A nova hermenêtica inscrita nas 'teologias da libertação' conduz a uma leitura essencialmente polftica das Escrituras. Assim, uma importância maior é dada ao evento do Exodo enquanto é libertação da servidão polftica"19.

Os te6logos latino-americanos respondem a isso insistindo na necessária unidade entre o espiritual e o material, a salvaçāo religiosa e a libertação social, a açāo de Deus e a história humana: "como quer o Conćlio de Calcedónia, sem confusão, sim, mas tambem sem separação". Precisamente por esta razão, o Exodo constitui a seus olhos "o modelo de todo processo de libertaçāo", e o primeiro núcleo querigmático de uma teologia da libertação 20 .

Como toda hermenêtica, a de Gutierrez e de seus amigos é inevitavelmente seletiva: os aspectos etnocêntricos e os castigos terriveis da cólera divina são negligenciados propositalmente em proveito da dimensāo universal e humanística da auto-emancipação - com a ajuda e a inspiração divinas - dos escravos. Para Gutierrez, a "liçāo do Exodo" É antes de tudo a da "construção do homem por si mesmo na luta política histórica"21. Um dos principais exegetas bíblicos brasileiros, Carlos Mesters, explicava assim a significação históricoreligiosa do Exodo por ocasiāo de um encontro nacional das comunidades eclesiais de base do Brasil, em abril de 1981:

"Deus não abandona o seu povo. Ele escuta os gritos do povo e ajuda o povo a libertar-se. Deus é pai, mas não é paternalista. É necessário que o povo tome consciência da opressão em que vive e se una em torno da esperança de libertação. Dirigidos por Moisés, os hebreus se revoltaram contra o farab e abandonaram o Egito, atravessando o Mar Vermetho" 22 (grifo do autor).

É então por que pode ser interpretado (com ou sem razão, pouco importa) neste sentido, porque $\ell$, de todas as passagens das Escrituras, aquela que parece corresponder de maneira mais direta à idéia-força da autolibertação dos pobres, que o Exodo se tornará um texto paradigmático para a teologia da libertaçāo.

Evidentemente, não se trata de.uma comparação histórica efetiva, mas da atualizaçâo de uma herança espiritual e religiosa milenar, carregada, a cada momento da história, de uma significação presente, de um tempo de agora (para usar um conceito de Walter Benjamin que me parece aqui pertinente). É neste sentido que Gutierrez pode escrever que o povo pobre da América Latina se encontra "como exilado em sua própria terra", mas tambem, ao mesmo tempo, "em marcha de éxodo para o seu resgate"23. Por sua vez o padre chileno Rolando Muñoz, um dos conselheiros teológicos da Confederação Latino-Americana dos Religiosos (CLAR), fala da "linha de continuidade" entre o povo

18 GUTIERREZ, G. Théologie de la libération... op. cit., p. 157, 161.

19 Teologias da libertação... loc. cit.

20 BOFF, L. e BOFF, C. Teologia da libertação no debate atual. Petropolis, Vozes, 1985. p. 30-32 e Severino Croatto, apud KIRK, J.A. Liberation theology. An evangelical view from the Third World. Londres, Marshall Morgan and Scott, 1980. p. 101.

21 Théologie de la libération... op. cit., p. 166.

22 MESTERS, C. Deus liberta seu povo. In: FREI BETTO. O'fermento na massa. Petrópolis, Vozes, 1983. p. 57.

23 La force historique... op. cit., p. 106. 
sofredor de hoje e o povo de Israel oprimido no Egito ${ }^{24}$. O Exxodo serve assim como exemplo bíblico de uma salvação não individual e privada, mas comunitária e pública, em que não está em jogo a alma do indivíduo como tal, mas a redençấo - no dúplice sentido religioso e social do conceito hebreu gue'ulah - de todo um povo.

Como em todo círculo hermenêutico, o sujeito desta leitura encontra-se no texto do Antigo Testamento e lê a sua própria realidade à luz das Escrituras:

"No interior do tratamento hermenêutico, é perfeitamente legítimo compreendermos nós mesmos a partir do Êxodo bíblico e sobretudo compreender este do interior da nossa situação de povo em escravidão econômica, política, social e cultural",25.

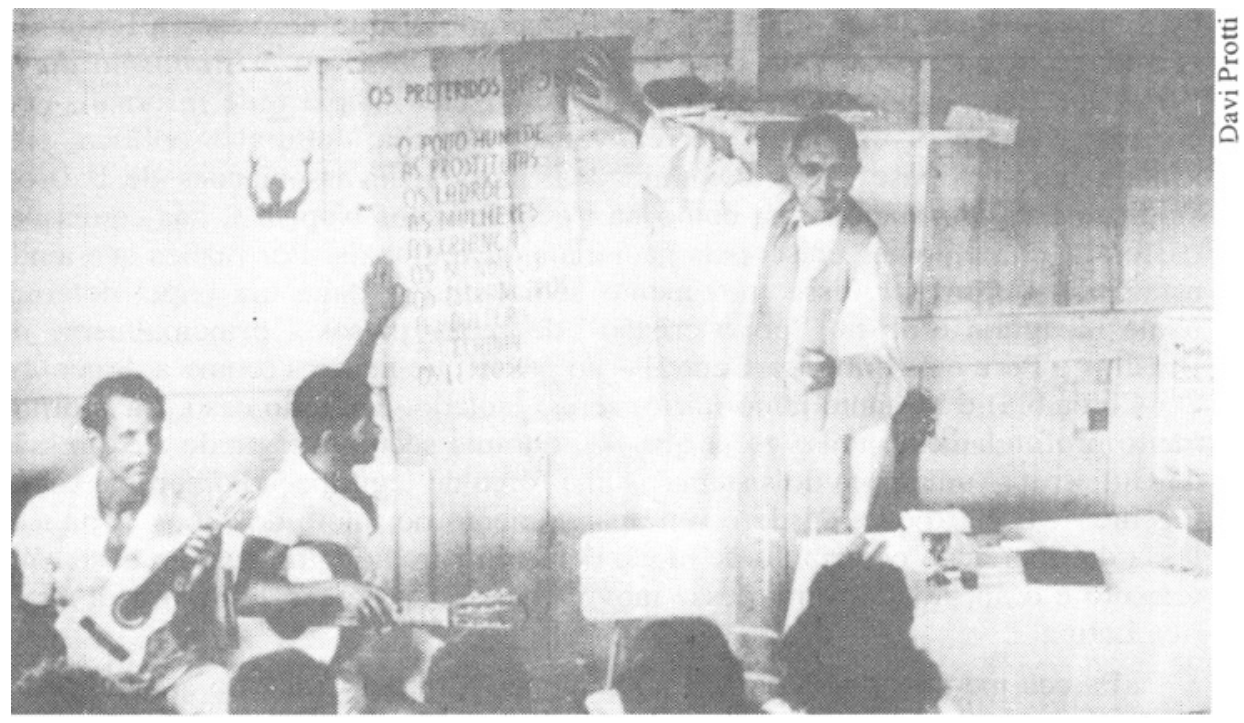

Esta leitura do Antigo Testamento é pois inseparável de uma escolha social e ético-religiosa: a opção prioritária pelos pobres - ou, mais exatamente, a solidariedade com o seu movimento de auto-emancipação. Segundo Pablo Richard (teólogo chileno que vive na América Central), “a Bíblia pertence à memória histórica e subversiva dos pobres. Estes devem apropriar-se dela nas Igrejas e lê-la a partir da sua própria história, de suas lutas de libertação. A exegese, a explicação científica da Bíblia, tem um sentido quando está a serviço dessa primeira leitura feita pelos pobres"26.

Não se há de concluir, entretanto, das observações acima, que a teologia da libertação seja prioritariamente fundamentada numa leitura do Antigo Testamento. Pelo contrário, as fontes neotestamentárias e a cristologia ocupam lugar muito mais importante em seu sistema de referências escriturais. Gutierrez tem pois razão de rejeitar como "claramente inexata" a afirmação segundo a qual a teologia da libertaçāo seria "exclusivamente centrada sobre o tema do Exodo e sobre o Antigo Testamento" 27.

${ }^{24}$ MUÑOZ, R. The historical vocation of the Church. In: GIBELLINI, R. Frontiers of theology... op. cit., p. 157.

25 Severino Croatto apud KIRK, J.A. Liberation theology. An evangelical view from the Third World. Londres, 1980. p. 102.

${ }^{26}$ La Bible, mémoire historique des pauvres. Liaisons Internationales. Bruxelas, (32): 3 , set. 1982.

${ }^{27}$ La force historique... op. cit., p. 214. 


\section{Um Movimento da Periferia para o Centro}

Como explicar em termos sociológicos o aparecimento deste movimento corrente, em ruptura com uma longa tradição conservadora e retrógrada? Por que essa teologia (e a sua leitura da Bíblia) puderam surgir no seio da Igreja latino-americana num momento histórico determinado?

A primeira observação a fazer a esse respeito é que a teologia da libertação é apenas a ponta visível do iceberg, a expressāo espiritual sistemática de uma mudança profunda no seio da Igreja e do povo cristäo muito anterior à publicação das primeiras obras dos novos teólogos. Leonardo Boff não se engana ao insistir que a teologia da libertação é reflexo de e reflexão sobre uma práxis preexistente. Mais exatamente, ela é a expressão - enquanto sistema coerente de valores e idéias - de todo um movimento social que atravessa a Igreja e a sociedade, a que se poderia chamar Igreja dos pobres ou cristianismo da libertaçâo. Esse movimento apresenta-se como uma ampla rede informal, uma corrente vasta e diversificada de renovação religiosa, cultural e política, presente tanto "na base", nas comunidades, paróquias, associaçóes de bairros, sindicatos, ligas camponesas, como na "cúpula", nos bispados, nas comissões pastorais, conferências episcopais nacionais ou regionais. Por razões que ainda estão por determinar, esse movimento social desempenha um papel determinante na Igreja e/ou no "povo cristão" de certos países - principalmente no Brasil, no Peru e na América Central - ao passo que noutros (como a Argentina e a Colômbia) é bastante minoritário, senão isolado. Em todo caso, transtornou muito profundamente uma Igreja que foi, durante séculos, segundo a expressão de Gutierrez, "uma peça do sistema", uma força de legitimação da ordem social vigente $^{28}$. É claro que, desde o seu aparecimento no início dos anos 70 , a teologia da libertação contribuiu de modo decisivo para a legitimação, o desenvolvimento e o aprofundamento desse movimento social na escala de toda a América Latina.

Parece-me que a abordagem mais eficaz para dar conta do aparecimento na América Latina do movimento social cristianismo da libertação e de sua expressão teológica é aquela que parte da articulação ou convergência entre a mudança interna e externa na Igreja em fins dos anos 50. A mudança interna diz respeito ao conjunto da Igreja católica: é o desenvolvimento, desde a Segunda Guerra Mundial, de novas correntes teológicas (Bultmann, Metz, Rahner, Congar, Chenu, Duquoc), de novas formas de cristianismo social (os padres operários, a economia humanista do Padre Lebret), de uma abertura crescente para as interrogações da filosofia moderna e das ciências sociais. O pontificado de João XXIII e o Concílio Vaticano II vão legitimar e sistematizar essas novas orientações, constituindo assim o ponto de partida para uma nova época na História da Igreja. No mesmo momento, desenvolve-se na América Latina uma profunda mudança social: a industrialização do continente, a partir dos anos 50 (sob o impulso do capital multinacional), vai "desenvolver o subdesenvolvimento" (segundo a conhecida fórmula de André Gunder-Frank), isto é, agravar a dependência, aprofundar as contradições sociais, estimular o êxodo rural e o crescimento das cidades, concentrando em zonas urbanas um imenso “pobretariado". Com a revolução cubana de 1959, abre-se na América Latina um período histórico novo, caracterizado pela intensificação das lutas sociais, o aparecimento dos movimentos de guerrilha, a sucessão dos golpes militares e a crise de legitimidade do sistema político. É a constelação desses dois tipos de mudança que criará as condições de possibilidade para a emergência da nova Igreja dos pobres, cujas origens são anteriores ao Vaticano II.

O novo movimento social surge primeiro nos grupos que se encontram na interseção das duas mudanças: os movimentos leigos (e certos membros do cle-
(...) o processo de radicalização da cultura católica latino-americana que vai culminar com a formação da teologia da libertação não parte do topo para a base da Igreja...

28 Théologie de la libération... op. cit., p. 206. 
ro) ativos na juventude estudantil, nos bairros periféricos, nos sindicatos urbanos e rurais e nas comunidades de base. Noutros termos: o processo de radicalização da cultura católica latino-americana que vai culminar com a formação da teologia da libertação não parte do topo para a base da Igreja, como parecem sugerir as análises funcionalistas sobre a busca de influência pela hierarquia, nem da base para o topo, como propõem certas interpretações populistas, mas da periferia para o centro. As categorias ou setores sociais na área religiosoeclesiástica que serão o motor da renovação são todos de certo modo marginais ou periféricos em relação à instituição: o apostolado leigo e os seus capelães, os peritos leigos, os padres estrangeiros, as ordens religiosas. Os primeiros bispos sensibilizados são aqueles que têm alguma ligação com uma ou outra dessas categorias. Em certos casos, o movimento ganha o centro e influencia as conferências episcopais (principalmente no Brasil), noutros, permanece às margens da instituição. Embora nascido no começo dos anos 60 , o novo movimento só se tornou um fenômeno maciço depois da conferência dos bispos latino-americanos em Medelin (1968), quando simultaneamente se desenvolvem as comunidades de base e, a partir da publicação do livro de Gutierrez em 1971, a teologia da libertação. No decorrer dos anos 70, as comunidades de base vão tornar-se um dos temas centrais da nova teologia ao mesmo tempo que a leitura do Antigo Testamento. Já nos anos 60, alguns teólogos latino-americanos, como José Miranda e Severino Croatto, se interessam pelo Antigo Testamento, mas o seu procedimento permanece relativamente isolado. É o desenvolvimento das comunidades de base que vai despertar um interesse crescente pela Bíblia judaica: também nisso pode-se dizer que a experiência social precedeu a reflexão teológica. Como sublinha, com razão, Daniel Levine, a leitura da Bíblia (particularmente do Antigo Testamento) é uma característica nova que unifica todas as comunidades de base cristās do continente:

"Eles lêem a Bíblia regularmente, discutem-na juntos e buscam nela a inspiração e a orientação. Nada disso era verdade em escala significativa antes de meados dos anos 60 . A promoção dos estudos bíblicos (...) teve enorme impacto sobre a qualidade da vida religiosa e a sua prática diária',29.

Ora, nessa leitura - orientada por leigos - é compreensível que a escolha dos animadores recaia mais particularmente sobre os textos e as imagens que parecem mais próximas da realidade atual do continente: por exemplo, as denúncias proféticas e o Exxodo. Para os animadores e participantes das comunidades de base "é no presente e não no passado que é preciso ler a Bỉblia, dando às palavras que ela contém todo o seu peso de realidade. Quando os profetas, e Moisés em primeiro lugar, falam do cativeiro e da escravatura, e anunciam o caminho aberto por Deus rumo à liberdade para o seu povo, essas palavras, para eles, iluminam o presente e o futuro. A dimensão espiritual dessa promessa não pode eliminar a dimensão histórica e concreta",30.

Noutras palavras: $e$ porque as comunidades cristãs de base estão engajadas numa prática emancipadora, num movimento social libertador que vão redescobrir e reinterpretar certas passagens das Escrituras (bastante negligenciadas pela exegese católica tradicional) como o Êxodo. A interpretação do Antigo Testamento pela teologia da libertação $\epsilon$, para retomar a fórmula de Leonardo Boff, o reflexo de e a reflexão sobre essa experiência religiosa e social nova das comunidades de base.

29 LEVINE, D.H. Religion and political conflict in Latin America. London, the University of North California Press, 1986. p. 10.

30 THOMAS, J.C. Ils n'arrêteront pas le printemps. p. 83.

Michel Löwy é diretor de pesquisas em sociologia do CNRS (Centre National de la Recherche Scientifique), França, e professor-visitante do IEA no segundo semestre de 1988. 